Article

\title{
Composting Process and Gas Emissions during Food Waste Composting under the Effect of Different Additives
}

\author{
Hyun Young Hwang ${ }^{\circledR}$, Seong Heon Kim, Jaehong Shim and Seong Jin Park* \\ Rural Development Administration, National Institute of Agricultural Sciences, Wanju 55365, Korea; \\ hyhwang2325@korea.kr (H.Y.H.); ksh4054@korea.kr (S.H.K.); jayshim@korea.kr (J.S.) \\ * Correspondence: archha98@korea.kr; Tel.: +82-63-238-2452
}

Received: 10 August 2020; Accepted: 18 September 2020; Published: 22 September 2020

check for updates

\begin{abstract}
This study investigated the effects of adding mature compost (MC) and vermicompost (VC) on controlling gas emissions and compost quality during food waste (FW) composting. In addition to a control treatment (only food waste), four treatments were designed to mix the initial FW with varying rates of $\mathrm{MC}$ and $\mathrm{VC}(5.0 \%$ and $7.5 \%)$. The composting process was monitored for 84 days. Results indicate that the addition of MC and VC resulted in higher temperature, prolonged the thermophilic stage and reduced $\mathrm{NH}_{3}$ and greenhouse gas (GHG) emissions. Compared to the control, the loss of $\mathrm{NH}_{3}-\mathrm{N}$ was decreased by $29-69 \%$, and the global warming impact was also mitigated by $49-61 \%$. The largest reductions in $\mathrm{NH}_{3}$ and global warming potential (GWP) were found for $7.5 \% \mathrm{VC}$ and $5 \% \mathrm{MC}$, respectively. The treatments with additives more rapidly achieved the required maturity value. This research suggests that the addition of $7.5 \% \mathrm{MC}$ and VC is suitable for food waste composting.
\end{abstract}

Keywords: ammonia; greenhouse gas; mature compost; vermicompost; kitchen waste

\section{Introduction}

Food wastes (FW) are produced throughout the food supply chain. Approximately 14,000 tons of FW are produced daily, and over five million tons need to be incinerated or disposed of landfills in Korea [1]. These disposal methods have caused environmental problems. Public attention toward FW treatment has increased with the growing interest of environmental issues.

Composting is a proper valorization strategy for FW involving the transformation of organic wastes into organic amendments [2,3]. The land application of compost can increase the level of soil organic carbon (SOC) stocks, improve the soil structure, and reduce the use of chemical fertilizer. However, one of the most important issues related to FW composting is associated with ammonia $\left(\mathrm{NH}_{3}\right)$ and greenhouse gases (GHGs) such as methane $\left(\mathrm{CH}_{4}\right)$ and nitrous oxide $\left(\mathrm{N}_{2} \mathrm{O}\right)$, which can contribute to global warming and stratospheric ozone depletion. The global warming potential (GWP) of $\mathrm{CH}_{4}$ and $\mathrm{N}_{2} \mathrm{O}$ is 25 and 298 times that of carbon dioxide $\left(\mathrm{CO}_{2}\right)$, respectively [4]. $\mathrm{NH}_{3}$ is the largest component of gaseous emissions during composting, and a precursor of small particulate matter $\left(\mathrm{PM}_{2.5}\right)$. Furthermore, the loss of $\mathrm{NH}_{3}$ reduces the nutrient quality of compost.

Several studies investigated various types of additives to decrease the loss of gases, such as coal ash [5], zeolite [6,7], vermiculite [8] and biochar $[9,10]$ for the composting of various organic waste types. In particular, the effects of mature compost (MC) were compared when mixed and when covered [11], and also under different mixing rates of MC [12]. However, the optimal mixing rate has not yet been discussed. Although data in the literature indicate that vermicompost (VC) contains humified, stable organic compounds [13], the application possibility of VC as an additive has not 
been well tested during food waste composting. Further studies of compost additives are required to provide proper strategies to mitigate the loss of gases in FW composting.

The aim of this study was to investigate the potentials of using MC and VC as additives to reduce GHGs and $\mathrm{NH}_{3}$ emissions during food waste composting. Their feasibility was explored with different quantities of two additives. The optimal additive material and its amount were identified and its nutrient content and maturity were also determined to evaluate its quality for compost production.

\section{Materials and Methods}

\subsection{Composting Materials}

For the experiment, food waste was obtained from an enclosed, local municipal waste collection station (Damyang, Korea). Its effective composition included vegetables, fruits, staple food, and meat. The food waste (30 kg wet weight) was mixed with $30 \%(w / w)$ sawdust (9 $\mathrm{kg}$ wet weight) to control the $\mathrm{C} / \mathrm{N}$ ratio between 20 and 30 and the initial moisture content to about $60 \%$. As shown in Table 1 , food waste has high electrical conductivity due to the sodium content and relatively great nitrogen concentration. Mature compost (MC) and vermicompost (VC) were then incorporated into the initial composting stock with varying rates of $5 \%$ and $7.5 \%$ of the fresh weight of the compost pile. The food waste compost without MC or VC was taken as the control. The five treatments were labeled as follows: $5 \% \mathrm{MC}, 7.5 \% \mathrm{MC}, 5 \% \mathrm{VC}, 7.5 \% \mathrm{VC}$, and control. Mature compost from a previous composting test and VC sold in market were used in this study. Detailed characteristics of the food waste, mature compost, vermicompost, and sawdust are shown in Table 1.

Table 1. Properties of the composting materials (mean value \pm standard deviation from triplicate measurements).

\begin{tabular}{|c|c|c|c|c|}
\hline Parameter & Food Waste & Mature Compost & Vermicompost & Sawdust \\
\hline Total C (\%) & $44.9 \pm 0.1$ & $39.3 \pm 0.3$ & $8.1 \pm 0.2$ & $48.7 \pm 0.3$ \\
\hline Total N (\%) & $5.1 \pm 0.03$ & $1.1 \pm 0.05$ & $0.79 \pm 0.07$ & $0.12 \pm 0.00$ \\
\hline $\mathrm{C} / \mathrm{N}$ ratio & $8.8 \pm 0.1$ & $35.1 \pm 1.7$ & $10.2 \pm 0.8$ & $400 \pm 17.7$ \\
\hline $\operatorname{DOC}\left(\mathrm{g} \mathrm{kg}^{-1}\right)^{1}$ & $107 \pm 13$ & $6.3 \pm 0.22$ & $1.2 \pm 0.05$ & $5.6 \pm 0.08$ \\
\hline $\mathrm{DON}\left(\mathrm{g} \mathrm{kg}^{-1}\right)^{1}$ & $16.4 \pm 2.1$ & $2.8 \pm 0.04$ & $2.1 \pm 0.08$ & $0.27 \pm 0.004$ \\
\hline $\operatorname{HWEC}\left(\mathrm{g} \mathrm{kg}^{-1}\right)^{1}$ & $25.2 \pm 3.0$ & $4.2 \pm 0.12$ & $1.7 \pm 0.09$ & $3.8 \pm 0.13$ \\
\hline $\operatorname{HWEN}\left(\mathrm{g} \mathrm{kg}^{-1}\right)^{1}$ & $3.2 \pm 0.36$ & $1.1 \pm 0.02$ & $0.32 \pm 0.002$ & $0.11 \pm 0.003$ \\
\hline $\mathrm{EC}\left(\mathrm{dS} \mathrm{m}^{-1}\right)^{1}$ & $7.0 \pm 0.1$ & $2.6 \pm 0.07$ & $2.2 \pm 0.03$ & $0.25 \pm 0.02$ \\
\hline $\mathrm{pH}$ & $4.9 \pm 0.1$ & $7.4 \pm 0.1$ & $7.0 \pm 0.1$ & $5.3 \pm 0.1$ \\
\hline
\end{tabular}

${ }^{1}$ DOC and DON: dissolved organic carbon and nitrogen, HWEC and HWEN: hot water extractable carbon and nitrogen, EC: electrical conductivity.

\subsection{Experiment Design}

The conventional static chamber method was chosen to perform this composting experiment for the spring-summer season. Five $62 \mathrm{~L}$ plastic boxes covered with $5 \mathrm{~cm}$ thick polystyrene were used to prevent heat loss. The treatments were not replicated because the composting scale ensured experimental reproducibility, as evidenced in other studies [14-16]. The temperature of all compost piles was continuously monitored using a data logger (EM50 Data logger, Washington, DC, USA).

\subsection{Sampling and Analytical Methods}

Greenhous gases (GHGs) such as carbon dioxide $\left(\mathrm{CO}_{2}\right)$, methane $\left(\mathrm{CH}_{4}\right)$ and nitrous oxide $\left(\mathrm{N}_{2} \mathrm{O}\right)$ were collected on days 2, 9, 16, 23, 30, 37, 44, 51, 61, 71 and 84 using the closed chamber method. The concentrations of GHGs were quantified using gas chromatography with a methanizer (Shimadzu, GC-2010, Tokyo, Japan). $\mathrm{NH}_{3}$ was captured using $0.1 \mathrm{~mol} \mathrm{~L}^{-1}$ sulfuric acid. The ammonia concentration in the acid was analyzed using Auto Analyzer 3 (Bran Luebbe, Hamburg, Germany). Details related to the sampling and measurement of gases are clearly explained in a previous study [16]. 
During the 84 days of composting, the compost piles were turned over and thoroughly mixed every week at the fixed time of 09:00. After turning, compost piles were collected by a sampling core at three points. The collected samples were divided into two parts; one portion was preserved at $4{ }^{\circ} \mathrm{C}$ before analysis, and the other portion was air-dried, ground and sieved with a $2 \mathrm{~mm}$ mesh.

Total organic carbon and nitrogen contents were quantified using an elemental analyzer (CHNS-932 Analyzer, Leco, Calagry, AB, Canada). The compost samples were shaken with distilled water (1:20 w/w) for $2 \mathrm{~h}$, and $\mathrm{pH}$ and electrical conductivity (EC), an index of salinity of food waste, were measured by $\mathrm{pH}$ and EC meter (Orion 3star, Thermo Electron Corporation, Waltham, MA, USA). The extract was filtered through a $0.45 \mu \mathrm{m}$ membrane filter to analyze the water extractable carbon and nitrogen concentration; subsequently, hot water extractable $\mathrm{C}$ and $\mathrm{N}$ were extracted using distilled water at $80^{\circ} \mathrm{C}$ for $16 \mathrm{~h}$, as they are relatively labile organic compounds. Concentration was determined using a TOC-5050A analyzer (Shimadzu Corporation, Tokyo, Japan). Fresh samples were extracted using $2 \mathrm{M}$ potassium chloride $(1: 10, w / v)$ to determine the concentration of ammonium $\left(\mathrm{NH}_{4}{ }^{+}\right)$and nitrate $\left(\mathrm{NO}_{3}{ }^{-}\right)$using a segmented flow analyzer (Bran Luebbe, Hamburg, Germany). The germination index (GI) was used to assess the phytotoxicity of the compost $[16,17]$.

\subsection{Statistical Analysis}

Principle component analysis was performed using R software to determine the relationship between compost characteristics and gas emissions for all treatments during composting. For each treatment, the correlation among composting properties was calculated and illustrated through a heat map using R software at a statistical significance level of 0.05 .

\section{Results and Discussion}

\subsection{Changes in Gas Emissions during Composting}

The dominant emissions of $\mathrm{NH}_{3}$ occurred during the initial thermophilic phase. From the 30th day to the end of composting, the $\mathrm{NH}_{3}$ volatilization rate showed a declining trend before lastly tending to the baseline (Figure 1a). The 7.5\% MC, 5\% VC and 7.5\% VC peaked at day $9(59,69$ and $\left.55 \mathrm{mg} \mathrm{kg}^{-1} \mathrm{~h}^{-1}\right)$, whereas the control and 5\% MC peaked later at day $23\left(75\right.$ and $58 \mathrm{mg} \mathrm{kg}^{-1} \mathrm{~h}^{-1}$ ). This was possibly due to the conversion of ammonium $\left(\mathrm{NH}_{4}{ }^{+}\right)$to $\mathrm{NH}_{3}$, which was attributed to the rapid biodegradation of organic nitrogen $(\mathrm{N})$ to inorganic $\mathrm{N}$. $\mathrm{NH}_{4}{ }^{+}$can volatilize becoming $\mathrm{NH}_{3}$ under high temperature and high $\mathrm{pH}$ conditions. The trends of $\mathrm{NH}_{3}$ production correlated with temperature, albeit with a delayed and slower decrease; this result agrees with the results of He et al. [8] and Zhang et al. [18], who investigated food waste composting using vermiculite and volatile sulfur compounds, respectively.

The use of $\mathrm{MC}$ and VC significantly reduced $\mathrm{NH}_{3}$ emissions during composting. Specifically, the $7.5 \% \mathrm{MC}$ and $7.5 \% \mathrm{VC}$ treatments effectively reduced $\mathrm{NH}_{3}$ emissions in the thermophilic phase (Figure 1a). A lower reduction was observed in the 5\% MC and VC treatments. Both $7.5 \%$ treatments showed a negligible level from 23 rd day onward; however, the $5 \%$ treatments experienced dramatic drops on days 30 and 37. This result agrees with that reported by Yang et al. [12] who found that adding mature compost could decrease initial $\mathrm{NH}_{3}$ production via adsorption and subsequent nitrification.

$\mathrm{N}_{2} \mathrm{O}$ emissions were effectively reduced by the addition of MC and VC throughout the composting period (Figure 1b). Methanotrophic bacteria can oxidize $\mathrm{NH}_{3}$ to $\mathrm{N}_{2} \mathrm{O}$ as reported in many studies $[19,20]$. This finding could also be confirmed by the results of this study, whereby the highest $\mathrm{N}_{2} \mathrm{O}$ emissions were found in the control, which produced the greatest $\mathrm{NH}_{3}$ volatilization rate. Since high temperature (over $40^{\circ} \mathrm{C}$ ) can hinder the activity of nitrifiers, the considerable $\mathrm{N}_{2} \mathrm{O}$ emissions in the thermophilic stage were possibly due to $\mathrm{NH}_{4}{ }^{+}$oxidization by methanotrophs [21,22]. 


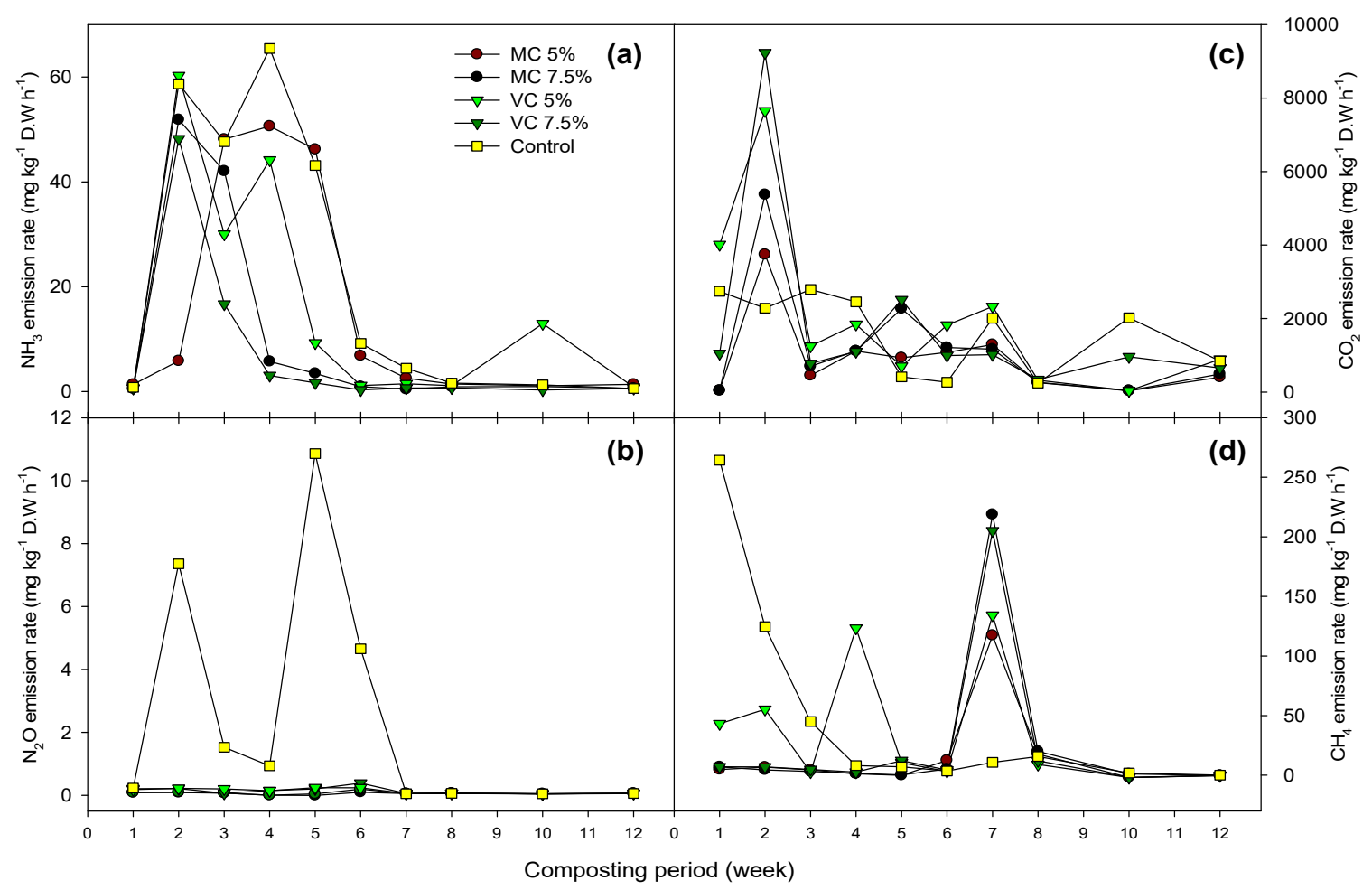

Figure 1. (a) Ammonia, (b) carbon dioxide, (c) nitrous oxide, and (d) methane emissions from different treatments during composting. MC 5\%: kitchen waste+sawdust+5\% mature compost; MC 7.5\%: kitchen waste+sawdust $+7.5 \%$ mature compost; VC 5\%: kitchen waste+sawdust $+5 \%$ vermicompost; VC 7.5\%: kitchen waste+sawdust+7.5\% vermicompost, Control: kitchen waste+sawdust.

$\mathrm{CH}_{4}$ emissions showed a considerable difference among treatments (Figure 1d). Although aeration was provided, anaerobic zones could still have been present in the composting pile due to methanogenic activity leading to rapid $\mathrm{O}_{2}$ consumption [23]. For the control treatment, $\mathrm{CH}_{4}$ emissions significantly increased within 10 days and then dramatically decreased to zero, whereas the $5 \% \mathrm{MC}, 7.5 \% \mathrm{MC}$ and $7.5 \% \mathrm{VC}$ treatments showed peak emissions on week 7 of composting. $\mathrm{CH}_{4}$ emission peaks of $264 \mathrm{mg} \mathrm{kg}^{-1} \mathrm{~h}^{-1}$ (Week 1), $218 \mathrm{mg} \mathrm{kg}^{-1} \mathrm{~h}^{-1}$ (Week 7), $205 \mathrm{mg} \mathrm{kg}^{-1} \mathrm{~h}^{-1}$ (Week 7), $134 \mathrm{mg} \mathrm{kg}^{-1} \mathrm{~h}^{-1}$ (Week 7) and $117 \mathrm{mg} \mathrm{kg}^{-1} \mathrm{~h}^{-1}$ (Week 7) were recorded for the control, 7.5\% MC, 7.5\% VC, 5\% VC and $5 \% \mathrm{MC}$ treatments, respectively. Since MC and VC can enhance the air space and adjust the moisture level, with other bulking agents, initial $\mathrm{CH}_{4}$ production could have been reduced. Interestingly, the $5 \%$ VC emitted slightly more $\mathrm{CH}_{4}$ than the other additive treatments did in the initial phase, which could have been due to it having the highest $\mathrm{CO}_{2}$ production. A high $\mathrm{CO}_{2}$ concentration would be favorable for $\mathrm{CO}_{2}$-dependent methanogenesis in the compost pile, as confirmed by the positive relationship between the $\mathrm{CH}_{4}$ and $\mathrm{CO}_{2}$ emission patterns (Figure 4).

Carbon dioxide emission is an indicator of microbial activity and the degradation of organic matter (OM) [24,25]. Overall, the $\mathrm{CO}_{2}$ emissions of each treatment were greater in the initial thermophilic phase when the decomposition of organic matter was faster. $\mathrm{CO}_{2}$ emission peaks of $9.23 \mathrm{~g} \mathrm{~kg}^{-1} \mathrm{~h}^{-1}$ (Week 2), $7.65 \mathrm{~g} \mathrm{~kg}^{-1} \mathrm{~h}^{-1}$ (Week 2), $5.37 \mathrm{~g} \mathrm{~kg}^{-1} \mathrm{~h}^{-1}$ (Week 2), $3.74 \mathrm{~g} \mathrm{~kg}^{-1} \mathrm{~h}^{-1}$ (Week 2) and $2.74 \mathrm{~g} \mathrm{~kg}^{-1} \mathrm{~h}^{-1}$ (Week 1) were recorded for the $7.5 \% \mathrm{VC}, 5 \% \mathrm{VC}, 7.5 \% \mathrm{MC}, 5 \% \mathrm{MC}$ and control treatments, respectively (Figure 1c).

\subsection{Changes in Temperature and $p H$ during Composting}

A composting period is generally divided into thermophilic, mesophilic, and curing phases with the mineralization of organic materials. Temperature changes recorded for all treatments are illustrated in Figure 2a. 
(a)

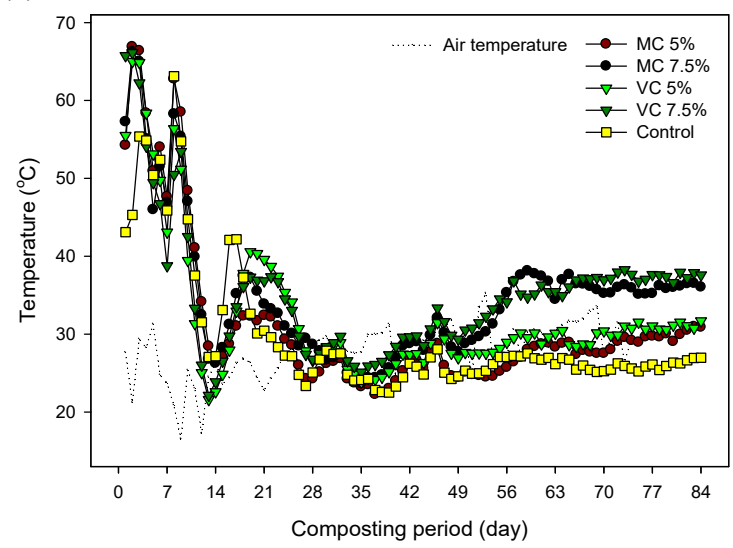

(b)

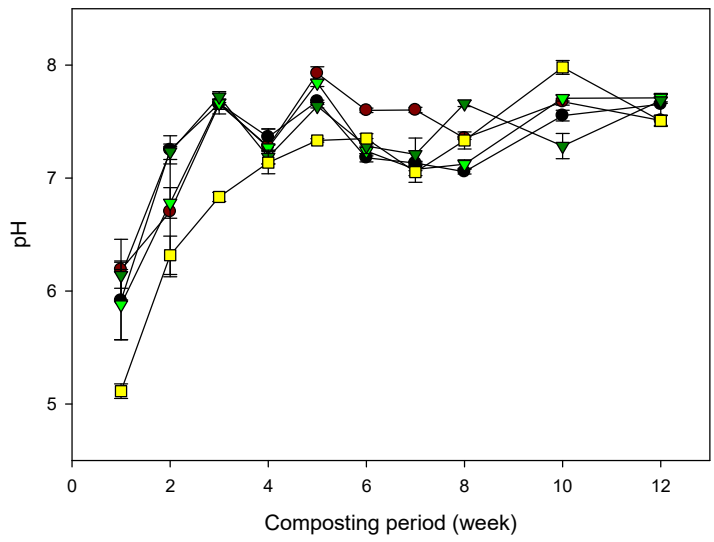

Figure 2. Changes in (a) temperature and (b) $\mathrm{pH}$ during composting. MC 5\%: kitchen waste $+5 \%$ mature compost; MC 5\%: kitchen waste+sawdust $+5 \%$ mature compost; MC 7.5\%: kitchen waste+sawdust $+7.5 \%$ mature compost; VC $5 \%$ : kitchen waste+sawdust $+5 \%$ vermicompost; VC $7.5 \%$ : kitchen waste+sawdust $+7.5 \%$ vermicompost, Control: kitchen waste+sawdust.

It is generally accepted that $50^{\circ} \mathrm{C}$ is the threshold between the mesophilic and thermophilic phases of composting [26,27]. Except for the control, the temperature of all treatments rapidly increased and reached the thermophilic phase $\left(>50^{\circ} \mathrm{C}\right)$ on the first day of composting before remaining above this level at least for 12 days (Figure 2a), indicating the active biodegradation of organic matter. The treatments containing mature compost and vermicompost attained the highest temperature on day $2\left(65-67^{\circ} \mathrm{C}\right)$, while the control treatment reached the highest temperature on day 8 of composting $\left(63^{\circ} \mathrm{C}\right)$. This was mainly due to the intensive degradation of $\mathrm{OM}$. With the steady depletion of biodegradable organic matters, all treatments showed a decline in temperature. However, the temperature of the $7.5 \% \mathrm{MC}$ and $7.5 \%$ VC treatments gradually increased to $40{ }^{\circ} \mathrm{C}$, which was maintained during the curing phase (Figure 2a), possibly due to the additives. Other treatments trended toward ambient temperature on day 29, implying the stabilization of decomposition.

The degradation of organic matter was correlated with an increase in the $\mathrm{pH}$ of the composting pile (Figure $2 \mathrm{~b}$ ), which in turn favored $\mathrm{NH}_{3}$ volatilization. The $\mathrm{pH}$ of all treatments followed a similar trend, with a rapid increase within 3 weeks, followed by the maintenance of an alkaline state. This occurred because the high temperature led to the volatilization of organic acids, thus increasing the $\mathrm{pH}$ value in all treatments. Concurrently, a large amount of $\mathrm{NH}_{3}$ was produced during this stage (Figure 1a). At the end of composting, the $\mathrm{pH}$ of all treatments ranged from 7.0 to 8.5, which reflected safe compost standards [28,29]. Principal component analysis (PCA) also confirmed that the $\mathrm{pH}$ had a positive relationship with the germination index (Figure 4).

\subsection{Compost Chemical Characteristics}

A faster increase in the germination index (GI) was observed for the additive treatments (Figure 3c). The GI value increased to above 80\%, indicating maturity [16,30], in week 5 to 6 and 6 to 7 for the MC and VC treatments, respectively, in comparison to that on week 7 for the control. Mature compost can accelerate the composting process, as a result of the succession of the microbial community [31]. 


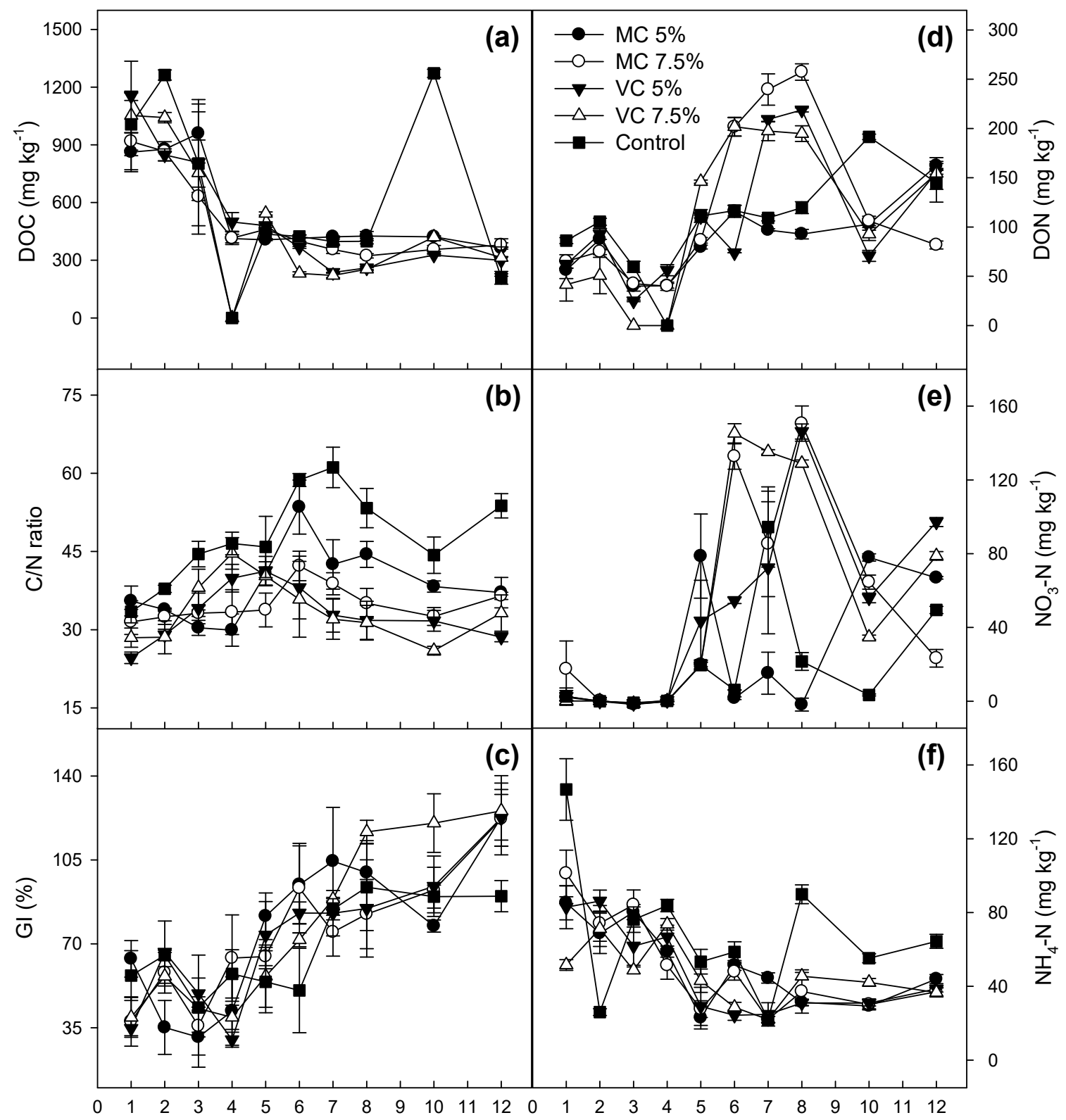

Composting period (week)

Figure 3. (a) Dissolved organic carbon, (b) dissolved organic nitrogen, (c) $\mathrm{C} / \mathrm{N}$ ratio, (d) $\mathrm{NO}_{3}-\mathrm{N}$, (e) germination index, and (f) $\mathrm{NH}_{4}{ }^{+}-\mathrm{N}$ content during composting. Error bars represent standard deviations of triplicate measurements. MC 5\%: kitchen waste+sawdust $+5 \%$ mature compost; MC 7.5\%: kitchen waste+sawdust $+7.5 \%$ mature compost; VC 5\%: kitchen waste+sawdust $+5 \%$ vermicompost; VC $7.5 \%$ : kitchen waste+sawdust $+7.5 \%$ vermicompost, Control: kitchen waste+sawdust.

The $\mathrm{C} / \mathrm{N}$ ratio initially increased; however, the values recorded for the initial and final compost products were not significantly different (Figure $3 b$ ). The final $\mathrm{C} / \mathrm{N}$ ratio values of all treatments ranged between 29 and 54, which were higher than the standard value $(<25)$, indicating compost maturity. In particular, compared to the additive treatments, a more substantial increase in $\mathrm{C} / \mathrm{N}$ ratio was found in the control treatment, possibly due to the substantial loss of $\mathrm{NH}_{3}-\mathrm{N}$. A proper $\mathrm{C} / \mathrm{N}$ ratio controlled by the initial composting stock and additives can provide optimal porosity and suitable composting conditions, thereby promoting composting action.

The initial dissolved organic carbon (DOC) content was relatively high, and DOC sharply decreased to approximately $400 \mathrm{mg} \mathrm{kg}^{-1}$ within 4 weeks in all composts (Figure 3a). The dissolved 
organic nitrogen $(\mathrm{DON})$ content in all treatment was considerably variable ranging during whole composting period, but trends in DON changes were similar for all composts examined (Figure 3d). The increase in DON concentration simultaneously occurred with increase in $\mathrm{NO}_{3}-\mathrm{N}$.

Changes in $\mathrm{NH}_{4}{ }^{+}-\mathrm{N}$ concentration can reflect nitrogen conversion during composting [32]. The $\mathrm{NH}_{4}{ }^{+}-\mathrm{N}$ content gradually decreased from the beginning of composting, which can be attributed to the $\mathrm{NH}_{3}$ volatilization and the conversion from $\mathrm{NH}_{4}{ }^{+}-\mathrm{N}$ to $\mathrm{NO}_{3}{ }^{-}-\mathrm{N}$ (Figure 3 e,f). $\mathrm{A}<40^{\circ} \mathrm{C}$ temperature and aeration are favorable for nitrification [33]. High temperature in the initial stage can inhibit the activity of nitrifying bacteria $[34,35]$. Therefore, the $\mathrm{NO}_{3}{ }^{-}-\mathrm{N}$ content of the five treatments started increasing from week 5 of composting. This trend was consistent with the PCA results. $\mathrm{NH}_{4}-\mathrm{N}$ showed positive correlation with $\mathrm{NH}_{3}$, but negative correlation with $\mathrm{NO}_{3}-\mathrm{N}$ (Figure 4).

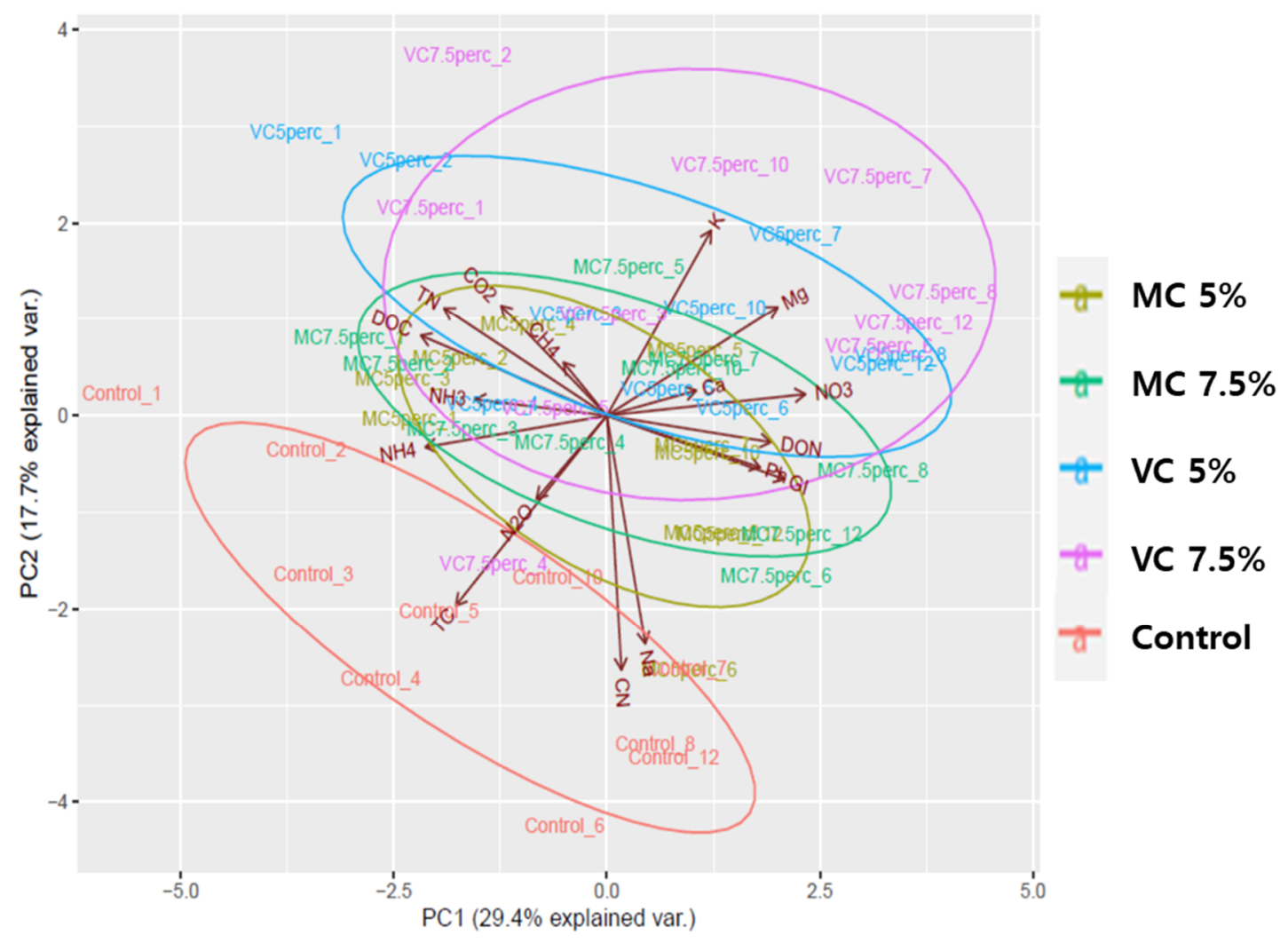

Figure 4. Principal-component analysis of correlation among physiochemical properties and ammonia and greenhouse gas emissions. MC 5\%: kitchen waste+sawdust+5\% mature compost; MC 7.5\%: kitchen waste+sawdust $+7.5 \%$ mature compost; VC 5\%: kitchen waste+sawdust $+5 \%$ vermicompost; VC $7.5 \%$ : kitchen waste+sawdust $+7.5 \%$ vermicompost, Control: kitchen waste+sawdust.

When the composting process was completed, the total nitrogen losses were $12.8 \%, 7.7 \%, 24.5 \%$, $18.5 \%$ and $60.0 \%$ for the $5 \% \mathrm{MC}, 7.5 \% \mathrm{MC}, 5 \% \mathrm{VC}, 7.5 \% \mathrm{VC}$ and control treatment, respectively. Hence, the addition of mature compost and vermicompost significantly decreased nitrogen loss in comparison with the control. This considerable loss of $\mathrm{N}$ in the control treatment led to a relatively higher $\mathrm{C} / \mathrm{N}$ ratio and overall lower nutrient status ( $, \mathrm{K}, \mathrm{Ca}$ and $\mathrm{Mg}$ ) in the final compost product (Table 2). 
Table 2. Mass and characteristics of initial and final compost.

\begin{tabular}{|c|c|c|c|c|c|c|c|c|c|}
\hline \multirow{2}{*}{ Treatment $^{1}$} & \multirow{2}{*}{ Composting Cycle } & \multirow{2}{*}{ Mass (kg) } & \multicolumn{7}{|c|}{ Content (\%) } \\
\hline & & & TOC & TN & $\mathrm{C} / \mathrm{N}$ & $\mathbf{K}$ & $\mathrm{Ca}$ & $\mathrm{Mg}$ & $\mathrm{Na}$ \\
\hline \multirow[t]{2}{*}{ MC 5\% } & Initial & 21.0 & 40.1 & 1.08 & 37.1 & 0.40 & 2.50 & 0.25 & 0.59 \\
\hline & Final & 18.7 & 37.2 & 1.00 & 37.2 & 0.43 & 2.97 & 0.32 & 0.95 \\
\hline \multirow[t]{2}{*}{ MC 7.5\% } & Initial & 21.5 & 40.1 & 1.09 & 36.8 & 0.51 & 2.83 & 0.20 & 0.56 \\
\hline & Final & 19.4 & 38.9 & 1.07 & 36.4 & 0.46 & 9.01 & 0.5 & 1.14 \\
\hline \multirow[t]{2}{*}{ VC $5 \%$} & Initial & 21.0 & 36.7 & 1.25 & 29.4 & 0.62 & 1.93 & 0.27 & 0.47 \\
\hline & Final & 18.2 & 29.5 & 1.03 & 28.6 & 0.50 & 4.14 & 0.61 & 0.88 \\
\hline \multirow[t]{2}{*}{ VC $7.5 \%$} & Initial & 21.5 & 32.3 & 0.99 & 32.6 & 0.46 & 2.44 & 0.32 & 0.35 \\
\hline & Final & 19.5 & 26.8 & 0.81 & 33.1 & 0.68 & 3.03 & 0.61 & 0.62 \\
\hline \multirow[t]{2}{*}{ Control } & Initial & 20.0 & 45.2 & 1.18 & 38.3 & 0.31 & 0.72 & 0.08 & 0.66 \\
\hline & Final & 12.3 & 42.1 & 0.78 & 54.0 & 0.39 & 1.41 & 0.20 & 1.08 \\
\hline
\end{tabular}

${ }_{1}^{1}$ MC 5\%: kitchen waste+sawdust+5\% mature compost; MC 7.5\%: kitchen waste+sawdust $+7.5 \%$ mature compost; VC $5 \%$ : kitchen waste+sawdust+5\% vermicompost; VC $7.5 \%$ : kitchen waste+sawdust $+7.5 \%$ vermicompost, Control: kitchen waste+sawdust. 


\subsection{Total Gas Fluxes and Global Warming Potential}

The use of two additives (mature and vermicompost) had significant effect on reducing the $\mathrm{NH}_{3}$ volatilization during composting (29-69\% compared to control). $\mathrm{NH}_{3}$ reduction was more dependent on addition rates than additive types. The $7.5 \% \mathrm{MC}$ and VC treatments significantly reduced $\mathrm{NH}_{3}$ emission by $54-69 \%$, which was a much greater reduction than that achieved by the $5 \%$ treatments (29-31\%) (Table 3). The 7.5\% VC addition was more effective in controlling $\mathrm{NH}_{3}$ emissions. Proper porosity of the initial compost stock plays an important role in reducing the $\mathrm{NH}_{3}$ emission [6]. Furthermore, vermicompost is widely known for its physiochemical properties, such as high porosity, good aeration, drainage and microbial activity [36].

Table 3. Ammonia, greenhouse gas and global warming potential (GWP) during composting.

\begin{tabular}{|c|c|c|c|c|c|}
\hline \multirow{2}{*}{ Compost $^{1}$} & $\mathrm{NH}_{3}$ & $\mathrm{CO}_{2}$ & $\mathrm{~N}_{2} \mathrm{O}$ & $\mathrm{CH}_{4}$ & \multirow{2}{*}{$\begin{array}{c}\text { Total GWP } \\
\text { kg CO} \\
\text { eq. } \text { kg }^{-1} \text { D.W }\end{array}$} \\
\hline & \multicolumn{4}{|c|}{$\mathrm{g} \mathrm{kg}^{-1}$ D.W } & \\
\hline MC 5\% & 34.8 & 1885 & 0.11 & 29.8 & 2.66 \\
\hline MC $7.5 \%$ & 22.6 & 2556 & 0.13 & 47.9 & 3.79 \\
\hline VC $5 \%$ & 34.0 & 4206 & 0.27 & 69.5 & 6.02 \\
\hline VC $7.5 \%$ & 15.3 & 3758 & 0.27 & 46.4 & 5.00 \\
\hline Control & 48.9 & 3240 & 4.73 & 88.1 & 6.85 \\
\hline
\end{tabular}

${ }^{1}$ MC 5\%: kitchen waste+sawdust+5\% mature compost; MC 7.5\%: kitchen waste+sawdust $+7.5 \%$ mature compost; VC $5 \%$ : kitchen waste+sawdust $+5 \%$ vermicompost; VC $7.5 \%$ : kitchen waste+sawdust $+7.5 \%$ vermicompost, Control: kitchen waste+sawdust.

The production of $\mathrm{CO}_{2}$ and $\mathrm{CH}_{4}$ is mainly responsible for microbial activity; the maximal $\mathrm{CO}_{2}$ emissions were observed in the $5 \% \mathrm{VC}$ treatment, while the lowest $\mathrm{CO}_{2}$ emissions were recorded in the 5\% MC. Compared with the control, the mature compost treatments ( 5 and $7.5 \% \mathrm{MC}$ ) reduced $\mathrm{CO}_{2}$ emissions by $40 \%$ and $20 \%$, whereas the vermicompost treatments ( 5 and $7.5 \% \mathrm{VC}$ ) increased $\mathrm{CO}_{2}$ emissions by $30 \%$ and $16 \%$, respectively. This was likely due to the higher nutrient profile in vermicompost than that in traditional compost, as reported by many studies $[37,38]$, and the relatively lower $\mathrm{C} / \mathrm{N}$ ratio of vermicompost (Table 1 ).

In this study, mature compost and vermicompost reduced $\mathrm{CH}_{4}$ emissions by $21-66 \%$ in comparison with the control treatment (Table 3). The additives could accommodate the increase in porosity of the compost pile, thereby mitigating the anaerobic conditions leading $\mathrm{CH}_{4}$ production [39].

The principle component analysis (PCA) can express the relation between gas emissions and chemical properties during the composting process (Figure 4). A cumulative proportion of $47 \%$ contributed by the selected factors. Data distribution of control treatment was differently found, compared to additives. Gases had positive correlation with temperature and $\mathrm{C} / \mathrm{N}$ ratio (Figure 4). In particular, $\mathrm{N}_{2} \mathrm{O}$ emissions showed a significantly positive correlation with total carbon, $\mathrm{Ca}$ and $\mathrm{Mg}$ content $(p<0.05)$. Total nitrogen was positively correlated with $\mathrm{NH}_{3}$ emissions but negatively correlated with GI $(p<0.05)$ (Figure 5).

Total global warming impact is expressed as $\mathrm{CO}_{2}$ equivalents using a global warming potential (GWP) of 1 for $\mathrm{CO}_{2}, 25$ for $\mathrm{CH}_{4}$, and 298 for $\mathrm{N}_{2} \mathrm{O}$ [4]. The total GWP value ranged from 2.7 to $6.9 \mathrm{~kg} \mathrm{CO}_{2}$ eq. $\mathrm{kg}^{-1}$ dry material. The $5 \% \mathrm{MC}$ treatment showed the greatest GWP reduction of $61 \%$ ( $2.7 \mathrm{~kg} \mathrm{CO}_{2}$ eq. $\mathrm{kg}^{-1}$ ), while the $7.5 \% \mathrm{MC}, 7.5 \% \mathrm{VC}$ and $5 \% \mathrm{VC}$ treatments followed with reductions of $45 \%\left(3.8 \mathrm{~kg} \mathrm{CO}_{2}\right.$ eq. $\left.\mathrm{kg}^{-1}\right), 27 \%\left(5.0 \mathrm{~kg} \mathrm{CO}_{2}\right.$ eq. $\left.\mathrm{kg}^{-1}\right)$ and $12 \%\left(6.0 \mathrm{~kg} \mathrm{CO}_{2}\right.$ eq. $\left.\mathrm{kg}^{-1}\right)$ compared to the control, respectively. In additive treatments, the contribution of the three GHGs to total GWP was biased, with values of $67-75 \%$ for $\mathrm{CO}_{2}, 1.0-1.6 \%$ for $\mathrm{N}_{2} \mathrm{O}$ and $23-32 \%$ for $\mathrm{CH}_{4}$. The control treatment showed a relatively even contribution pattern, with values of $47 \%$ for $\mathrm{CO}_{2}, 21 \%$ for $\mathrm{N}_{2} \mathrm{O}$ and $32 \%$ for $\mathrm{CH}_{4}$. The lowest values of $\mathrm{NH}_{3}$ production and GWP were found in the $7.5 \% \mathrm{VC}$ and $5 \% \mathrm{MC}$ treatments, respectively. 


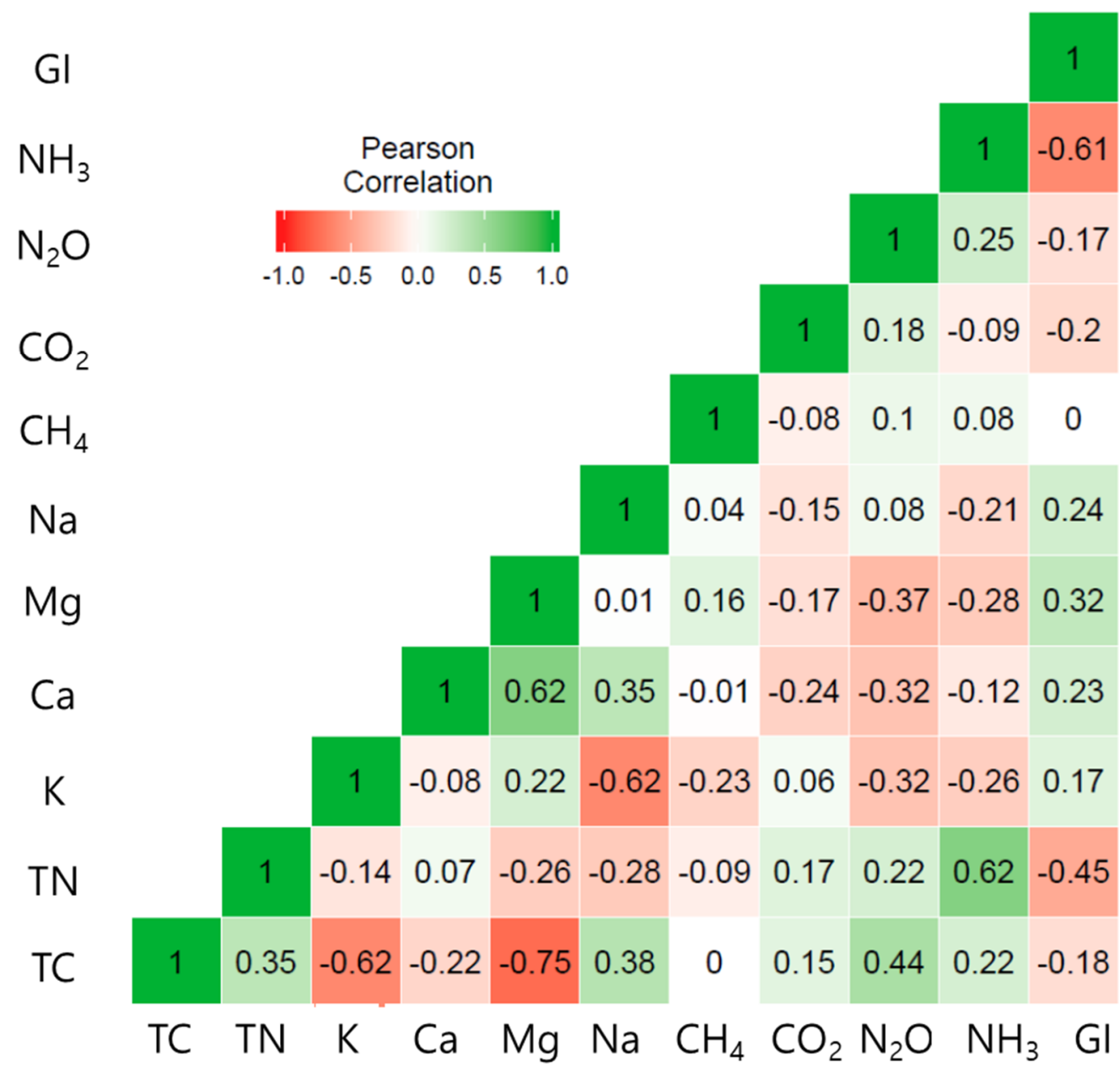

Figure 5. Pearson correlation analysis based on heat map of gaseous emissions and chemical properties during composting for each treatment MC 5\%: kitchen waste+sawdust+5\% mature compost; MC 7.5\%: kitchen waste+sawdust $+7.5 \%$ mature compost; VC 5\%: kitchen waste+sawdust $+5 \%$ vermicompost; VC 7.5\%: kitchen waste+sawdust $+7.5 \%$ vermicompost, Control: kitchen waste+sawdust.

\section{Conclusions}

This research indicated that the two additives reduced greenhouse gas and $\mathrm{NH}_{3}$ emissions, and improved compost quality. The addition of vermicompost effectively inhibited $\mathrm{NH}_{3}$ emissions, while the addition of mature compost significantly decreased global warming impact. After composting, various properties (total organic carbon (TOC), total nitrogen (TN), and $\mathrm{C} / \mathrm{N}$ ratio) and the nutrient status $(\mathrm{K}, \mathrm{Ca}$, and $\mathrm{Mg}$ ) of $\mathrm{MC}$ and $\mathrm{VC}$ treatments were better than those of the control. Although these results prove that modification with $\mathrm{MC}$ and $\mathrm{VC}$ is suitable for alleviating gas emissions and improving quality for food waste composting, a pilot-scale study is needed to assess its commercial and practical feasibility. As an additive, mature compost or vermicompost are strongly recommended for being beneficial to the composting process depending on the target gas to be reduced.

Author Contributions: Conceptualization, H.Y.H., S.H.K. and S.J.P.; data curation, H.Y.H., S.H.K., J.S. and S.J.P.; investigation, H.Y.H. and S.H.K.; methodology, H.Y.H., S.H.K., J.S. and S.J.P.; supervision, S.H.K., J.S. and S.J.P.; writing-original draft, H.Y.H.; writing-review and editing, H.Y.H., S.H.K. All authors have read and agreed to the published version of the manuscript.

Funding: This research received no external funding.

Acknowledgments: This research was supported by the Rural Development Administration (PJ01346801), Republic of Korea. 
Conflicts of Interest: The authors declare no conflict of interest.

\section{References}

1. Korea Ministry of Environment. Study on Preparation of Enhancement of Domestic Management System of the Waste in International Trade; Final Report, KME Report; Korea Ministry of Environment: Seoul, Korea, 2019.

2. Saer, A.; Lansing, S.; Davitt, N.H.; Graves, R.E. Life cycle assessment of a food waste composting system: Environmental impact hotspots. J. Clean. Prod. 2013, 52, 234-244. [CrossRef]

3. Hodge, K.L.; Levis, J.W.; DeCarolis, J.F.; Barlaz, M.A. Systematic evaluation of industrial, commercial and institutional food waste management strategies in the United States. Environ. Sci. Technol. 2016, 50, 8444-8452. [CrossRef] [PubMed]

4. $\quad$ Solomon, S. Climate Change 2007: The Physical Science Basis: Contribution of Working Group I to the Fourth Assessment Report of the Inter-Governmental Panel on Climate Change; Cambridge University Press: Cambridge, UK, 2007.

5. Belyaeva, O.N.; Haynes, R.J. Chemical, microbial and physical properties of manufactured soils produced by co-composting municipal green waste with coal fly ash. Bioresour. Technol. 2009, 100, 5203-5209. [CrossRef] [PubMed]

6. Awasthi, M.K.; Pandey, A.K.; Bundela, P.S.; Wong, J.W.C.; Li, R.; Zhang, Z. Co-composting of gelatin industry sludge combined with organic fraction of municipal solid waste and poultry waste employing zeolite mixed with enriched nitrifying bacterial consortium. Bioresour. Technol. 2016, 213, 181-189. [CrossRef] [PubMed]

7. Chan, M.T.; Selvam, A.; Wong, J.W.C. Reducing nitrogen loss and salinity during 'struvite' food waste composting by zeolite amendment. Bioresour. Technol. 2016, 200, 838-844. [CrossRef]

8. He, Z.; Lin, H.; Hao, J.; Kong, X.; Tian, K.; Bei, Z.; Tian, X. Impact of vermiculite on ammonia emissions and organic matter decomposition of food waste during composting. Bioresour. Technol. 2018, 263, 548-554. [CrossRef]

9. Awasthi, M.K.; Duan, Y.; Liu, T.; Awasthi, S.K.; Zhang, Z. Relevance of biochar to influence the bacterial succession during pig manure composting. Bioresour. Technol. 2020, 304, 122962. [CrossRef]

10. Awasthi, M.K.; Duan, Y.; Liu, T.; Awasthi, S.K.; Zhang, Z. Influence of bamboo biochar on mitigating greenhouse gas emissions and nitrogen loss during poultry manure composting. Bioresour. Technol. 2020, 303, 122952. [CrossRef]

11. Luo, W.H.; Yuan, J.; Luo, Y.M.; Li, G.X.; Nghiem, L.D.; Price, W.E. Effects of mixing and covering with mature compost on gaseous emissions during composting. Chemosphere 2014, 117, 14-19. [CrossRef]

12. Yang, F.; Li, Y.; Han, Y.; Qian, W.; Li, G.; Luo, W. Performance of mature compost to control gaseous emissions in kitchen waste composting. Sci. Total Environ. 2019, 657, 262-269. [CrossRef]

13. Jack, A.L.H.; Thies, J.E. Compost and vermicompost as amendments promoting soil health. In Biological Approaches to Sustainable Soil Systems; Uphof, N., Ball, A.S., Fernandes, E., Herren, H., Husson, O., Laing, M., Palm, C., Pretty, J., Sanchez, P., Sanginga, N., et al., Eds.; Routledge: Abingdon, UK, 2006; pp. 453-466.

14. Yang, Y.; Awasthi, M.K.; Ren, X.; Guo, H.; Lv, J. Effect of bean dregs on nitrogen transformation and bacterial dynamics during pig manure composting. Bioresour. Technol. 2019, 288, 121-130. [CrossRef] [PubMed]

15. Yang, F.; Li, G.X.; Yang, Q.Y.; Luo, W.H. Effect of bulking agents on maturity and gaseous emissions during kitchen waste composting. Chemosphere 2013, 93, 1393-1399. [CrossRef] [PubMed]

16. Hwang, H.Y.; Kim, S.H.; Kim, M.S.; Park, S.J.; Lee, C.H. Co-composting of chicken manure with organic wastes: Characterization of gases emissions and compost quality. Appl. Biol. Chem. 2020, 63, 1-10. [CrossRef]

17. RDA (Rural Development Administration, Korea). Quality Control and Utilization of Livestock Manure; National Institute of Agricultural Sciences: WanJu, Korea, 2012.

18. Zhang, H.; Li, G.; Gu, J.; Wang, G.; Li, Y.; Zhang, D. Influence of aeration on volatile sulfur compounds (VSCs) and $\mathrm{NH}_{3}$ emissions during aerobic composting of kitchen waste. Waste Manag. 2016, 58, 369-375. [CrossRef] [PubMed]

19. Kits, K.D.; Campbell, D.J.; Rosana, A.R.; Stein, L.Y. Diverse electron sources support denitrification under hypoxia in the obligate methanotroph Methylomicrobium album strain BG8. Front. Microbiol. 2015, 6, 1072. [CrossRef] 
20. Mohammadi, S.S.; Pol, A.; Alen, T.V.; Jetten, M.S.M.; Op den Camp, H.J.M. Ammonia oxidation and nitrite reduction in the verrucomicrobial methanotroph Methylacidiphilum fumariolicum SolV. Front. Microbiol. 2017, 8, 1901. [CrossRef]

21. Campbell, M.A.; Nyerges, G.; Kozlowski, J.A.; Poret-Peterson, A.T.; Stein, L.Y.; Klotz, M.G. Model of the molecular basis for hydroxylamine oxidation and nitrous oxide production in methanotrophic bacteria. FEMS Microbiol. Lett. 2011, 322, 82-89. [CrossRef]

22. Jiang, T.; Ma, X.; Tang, Q.; Li, G.; Schuchardt, F. Combined use of nitrification inhibitor and struvite crystallization to reduce the $\mathrm{NH}_{3}$ and $\mathrm{N}_{2} \mathrm{O}$ emissions during composting. Bioresour. Technol. 2016, 217, 210-218. [CrossRef]

23. Zeng, Y.; Amaury, D.G.; Patrick, D. Improving composting as a post-treatment of anaerobic digestate. Bioresour. Technol. 2016, 201, 293-303. [CrossRef]

24. Zhang, L.; Sun, X. Changes in physical, chemical, and microbiological properties during the two-stage co-composting of green waste with spent mushroom compost and biochar. Bioresour. Technol. 2014, 171, 274-284. [CrossRef]

25. Sanchez-Garcia, M.; Alburquerque, J.A.; Sanchwz-Mondero, M.A.; Roig, A.; Cayuela, M.L. Biochar accelerates organic matter degradation and enhances $\mathrm{N}$ mineralisation during composting of poultry manure without a relevant impact on gas emissions. Bioresour. Technol. 2015, 192, 272-279. [CrossRef] [PubMed]

26. Yu, H.; Huang, G.H. Effect of sodium acetate as a pH control amendment on the composting of food waste. Bioresour. Technol. 2009, 100, 2005-2011. [CrossRef] [PubMed]

27. Chang, R.; Li, Y.; Li, J.; Chen, Q.; Zhao, H.; Qi, Z. Influences of the Thermophilic Period on Biodegradation and Nitrogen Loss in Stimulated Vegetable Waste Composting. Glob. Ecol. Conserv. 2019, 18, e00623. [CrossRef]

28. Ameen, A.; Ahmad, J.; Raza, S. Effect of $\mathrm{pH}$ and moisture content on composting of Municipal solid waste. Int. J. Sci. Res. Publ. 2016, 6, 35-37.

29. Zhang, D.; Luo, W.; Yuan, J.; Li, G.; Luo, Y. Effects of woody peat and superphosphate on compost maturity and gaseous emissions during pig manure composting. Waste Manag. 2017, 68, 56-63. [CrossRef] [PubMed]

30. Tiquia, S.M.; Tam, N.F.Y.; Hodgkiss, I.J. Effects of composting on phytotoxicity of spent pig-manure sawdust litter. Environ. Pollut. 1996, 93, 249-256. [CrossRef]

31. Kato, K.; Miura, N. Effect of matured compost as a bulking and inoculating agent on the microbial community and maturity if cattle manure compost. Bioresour. Technol. 2008, 99, 3372-3380. [CrossRef]

32. Ren, L.M.; Schuchardt, F.; Shen, Y.J.; Li, G.X.; Li, C.P. Impact of struvite crystallization on nitrogen losses during composting of pig manure and cornstalk. Waste Manag. 2010, 30, 885-892. [CrossRef]

33. Sanchez-Monedero, M.A.; Roig, A.; Paredes, C.; Bernal, M.P. Nitrogen transformation during organic waste composting by the Rutgers system and its effects on $\mathrm{pH}, \mathrm{EC}$ and maturity of the composting mixtures. Bioresour. Technol. 2001, 78, 301-308. [CrossRef]

34. Kim, D.J.; Lee, D.I.; Keller, J. Effect of temperature and free ammonia on nitrification and nitrite accumulation in landfill leachate and analysis of its nitrifying bacterial community by FISH. Bioresour. Technol. 2006, 97, 459-468. [CrossRef]

35. Santos, A.; Bustamante, M.A.; Tortosa, G.; Moral, R.; Bernal, M.P. Gaseous emissions and process development during composting of pig slurry: The influence of the proportion of cotton gin waste. J. Clean. Prod. 2016, 112, 81-90. [CrossRef]

36. Pathma, J.; Sakthivel, N. Microbial Diversity of Vermicompost Bacteria That Exhibit Useful Agricultural Traits and Waste Management Potential; Springer Plus: Berlin/Heidelberg, Germany, 2012; Volume 1, p. 26.

37. Lazcano, C.; Domínguez, J. Effects of vermicompost as a potting amendment of two commerciallygrownornamental plant species. Span. J. Agric. Res. 2010, 8, 1260-1270. [CrossRef]

38. Lim, S.L.; Wu, T.Y. Determination of maturity in the vermicompost produced from palm oil mill effluent using spectroscopy, structural characterization and thermogravimetric analysis. Ecol. Eng. 2015, 84, 515-519. [CrossRef]

39. Chang, J.I.; Chen, Y.J. Effects of bulking agents on food waste composting. Bioresour. Technol. 2010, 101, 5917-5924. [CrossRef] [PubMed]

(C) 2020 by the authors. Licensee MDPI, Basel, Switzerland. This article is an open access article distributed under the terms and conditions of the Creative Commons Attribution (CC BY) license (http://creativecommons.org/licenses/by/4.0/). 